\title{
IMPLEMENTASI KOTA LAYAK ANAK DI KABUPATEN DEMAK
}

\author{
Moh. Rohmat Said ${ }^{\bowtie}$, Murtono, dan Sri Utaminingsih
}

Program Studi Magister Pendidikan Dasar, Universitas Muria Kudus

\section{Info Artikel}

Sejarah Artikel:

Diterima 12 Okt 2017

Disetujui 21 Nov 2017

Dipublikasikan Des 2017

Keywords: Child Rights,
Child Friendly City,
Education

Education

\section{Abstract}

This study purpose to determine the role and implementation of Child Friendly City in Demak District from an educational point of view. This research is done in the school environment in Demak District with the object of research are principals, students, parents and school committee. Qualitative approach with qualitative descriptive technique used in this research. Data analysis was obtained from interviews conducted on education and culture offices, social offices, principals, school committees, students as well as parents and student questionnaires and observations from researchers. The result of the research (1) the KLA implementation indicator in education of two of the eight indicators is appropriate ie non-smoking areas that have been applied in public places and the implementation of child-friendly schools whereas there are six indicators that include: , early childhood education, 12-year compulsory education, means of traveling from and to school and recreation and recreation facilities. (2) the implementation of $K L A$ in schools of six of the seven indicators is not yet optimal: business involvement in the fulfillment of children's rights, information facilities, non-smoking areas, 12-year compulsory education, means of traveling for children to and from schools as well as, child friendly school and facilities creation and recreation that is right.

\begin{abstract}
Abstrak
Penelitian ini bertujuan untuk mengetahui peran dan implementasi Kota Layak Anak di Kabupeten Demak dari sudut pandang pendidikan. Penelitian ini di lakukan di lingkungan sekolah di Kabupaten Demak dengan objek penelitian adalah kepala sekolah, siswa, orang tua dan komite sekolah. Pendekatan kualitatif dengan tehnik deskriptif kualitatif digunakan dalam penelitian ini. Analisis data diperoleh dari wawancara yang dilakukan terhadap Dinas pendidikan dan kebudayaan, Dinas sosial, kepala sekolah, komite sekolah, siswa dan juga orang tua serta angket siswa dan pengamatan dari peneliti. Hasil penelitian (1) indikator implementasi KLA dalam pendidikan dua dari delapan indikator sudah tepat yaitu kawasan tanpa rokok yang sudah diberlakukan di tempat umum dan penerapan sekolah ramah anak sedangkan yang belum optimal terdapat enam indikator meliputi : keterlibatan dunia usaha dalam pemenuhan hak anak, fasilitas informasi, pendidikan anak usia dini, wajib belajar 12 tahun, sarana perjalan anak dari dan ke sekolah serta fasilitas kreasi dan rekreasi. (2) implementasi KLA di sekolah lima dari tujuh indikator belum optimal yaitu:keterlibatan dunia usaha dalam pemenuhan hak anak, fasilitas informasi, kawasan tanpa rokok, wajib belajar 12 tahun, dan sarana perjalanan anak dari dan ke sekolah hanya sekolah ramah anak yang sudah tepat dan sarana kreasi dan rekreasi.
\end{abstract}

(C) 2017 Universitas Muria Kudus

E-mail: mohammadsaidabdullah@yahoo.co.id

murtono@umk.ac.id; sri.utaminingsih@umk.ac.id 


\section{PENDAHULUAN}

Kota layak anak atau Child Friendly City adalah gagasan oleh UNESCO. Dengan program Growing Up City (Lync, 1977). Tujuan dicetuskannya KLA adalah agar anak menggunakan dan menilai lingkungnnya. Indonesia telah meratifikasi Konvensi Hak Anak (KHA) dan mengacu pada tujuan pembangunan nasional. Undang-undang tentang perlindungan anak ternyata belum berdampak terhadap perlindungan dan hak anak.

Kementerian Pemberdayaan dan Perlindungan anak juga telah mengeluarkan peraturan tentang perlindungan anak. Dengan adanya kebijakan tersebut banyak daerah yang ada di Provinsi Jawa Tengah menetapkan kebijakan- kebijakan yang melindungi hak-hak anak yang disesuaikan dengan kebijakan otonomi daerah. Kota Solo dan Surabaya menjadi kota percontohan keberhasilan penerapan KLA.

Kebijakan tersebut membuat banyak daerah berkeinginan untuk mewujudkan Kota Layak Anak dan berlomba untuk dapat memenuhi indikator yang telah ditetapkan oleh pemerintah. Indikator yang ditetapkan terdiri dari berbagai kluster dan melbatkan banyak instansi. Indikator-indikator tersebut harus terpenuhi disamping dapat memenuhi hak anak, kota tersebut juga mendapat reward dari Kementerian Perempuan dan Perlindungan anak.

Demak berada di perlintasan jalur Pantura (Pantai Utara) karena letaknya yang sangat strategi ini maka tidak heran Demak berkembang menjadi Kabupaten yang sangat potensial. Tidak hanya itu Demak memiliki nilai historis yang tinggi, Demak dahulu sebuah kerajaan yang sangat berpengaruh dengan pencapaian di berbagai bidang.

Demak saat ini mengalami peningkatan diberbagai bidang baik pendidikan, ekonomi, pemerintahan dan sosial budaya yang yang tumbuh pesat. Pertumbuhan yang pesat ini perlu diimbangi dengan pelayanan yang baik, salah satunya dengan pemenuhan hak anak.

Kabupaten Demak berupaya mewujudkan Kota Layak Anak. Salah satu upaya yang dilakukan dengan di buatnya PERBUP No 9 Tahun 2014. Upaya yang dilakukan adalah dengan membuat kebijakan tentang Kota Layak Anak, menyediakan fasilitas, sarana dan prasarana penunjang.

\section{METODE PENELITIAN}

Penelitian menggunakan pendekatan kualitatif dengan teknik deskriptif kualitatif. Penelitian dilakukan di sepuluh sekolah di sepuluh kecamatan di Kabupaten Demak secara acak yang dimulai dari Juni sampai Agustus 2017.

Subyek penelitian ini adalah siswa Sekolah Dasar (A) Kepala sekolah (S), masyarakat (O), komite sekolah (K), dan Dinas (D) terkait yaitu Dinas Pendidikan dan Kebudayaan serta Dinas Sosial KP2A.

Pengumpulan data dilakukan dengan wawancara, angket, observasi dan analisis dokumen. Analisis data menggunakan model Miles dan Huberman dari wawancara: kepala sekolah, siswa, masyarakat, komite, Dindikbud dan Dinas Sosial, angket siswa, observasi. Pengujian keabsahan dalam penelitian ini dilakukan dengan triangulasi, dari sumber informan.

\section{HASIL DAN PEMBAHASAN}

Penelitian ini dilakukan di sepuluh SD di sepuluh Kecamatan, Dinas pendidikan dan Kebudayaan, Dinas Sosial dan KP2A di Kabupaten Demak dengan hasil sebagai berikut

Tabel 1. Hasil Implemetasi KLA dalam pendidikan dan di sekolah

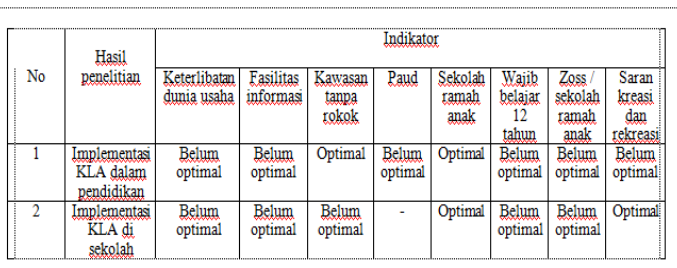

Indikator Kota Layak Anak dibedakan menjadi dua ditinjau dari pendidikan dan di sekolah:

1. Implementasi KLA dalam pendidikan meliputi: peran dunia usaha, fasilitas informasi, kawasan tanpa rokok, pendidikan anak usia dini, sekolah ramah anak, wajib belajar 12 tahun, fasilitas perjalanan ank dari dan ke sekolah serta fasiltas kreasi dan rekreasi.

a. Pemenuhan hak anak disekolah salah satunya adalah peran dunia usaha sebagai jembatan pendidikan dengan dunia usaha. Peran ini dibuktikan dengan adanya bantuan pendidikan yang diberikan dunia usaha kepada sekolah. Belum optimalnya peran dunia usaha terhadap pendidikan ini diperoleh data pada tahun 2013 satu dunia usaha yang terlibat pada tahun 2017 menjadi tiga dunia usaha dan keterlibatan masih bersifat temporar hal ini diperkuat pendapat D.1 dan D.2 yang mengatakan bahwa keterlibatan dunia usaha di Kabupaten Demak masih rendah. 
Tabel 2. Jumlah anak yang terlayani fasilitas informasi tahun 2013

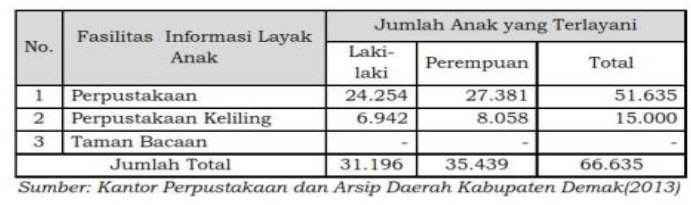

Tabel 3 Macam-macam media informasi layak anak yang dapat diakses di Perpustakaan Demak

\begin{tabular}{|c|c|c|c|c|}
\hline \multirow{2}{*}{$\begin{array}{c}\text { Jenis Media } \\
\text { Informasi Layak } \\
\text { Anak }\end{array}$} & \multirow{2}{*}{$\begin{array}{c}\text { Jumlah } \\
\text { judul }\end{array}$} & \multirow{2}{*}{\begin{tabular}{|c|} 
Jumlah \\
materi \\
/eksemplar
\end{tabular}} & \multicolumn{2}{|c|}{ Penerbit } \\
\hline & & & Lokal & Non lokal \\
\hline Buku/bacaan & 21.673 & 26.971 & $\mathrm{X}$ & \\
\hline Majalah & 19 & 2.122 & $\mathrm{X}$ & \\
\hline Internet & 5 & & & $\mathrm{X}$ \\
\hline Koran & 5 & 14.494 & $\bar{X}$ & \\
\hline Tabloid & 12 & 2.050 & $\mathrm{X}$ & \\
\hline APE & 50 & & & \\
\hline $\begin{array}{l}\text { Audio Visual/kaset } \\
\text { (keping) }\end{array}$ & 268 & & $\mathrm{x}$ & $\mathrm{X}$ \\
\hline
\end{tabular}

b. Fasilitas informasi belum optimal, Hasil dari data tabel diatas diperkuat dengan pendapat dari D.1 yang menyatakan terdapat Taman Bacaan Masyarakat (TBM) yang berjumlah 28, pojok baca untuk sekolah Paud berjumlah 799 dan $90 \%$ SD dan SMP sudah memiliki perpustakaan. Pendapat selaras juga disampaikan oleh D.2 yang menyatakan bahwa terdapat 28 TBM, 799 perpustakaan di Paud. Hal serupa juga terdapat di sekolah dasar 107 dari 492 sekolah yang terdapat dalam di Kabupaten Demak dalam jenjang sekolah dasar belum memiliki fasilitas informasi berupa perpustakaan sedangkan 385 sekolah sudah memiliki perpustakaan.

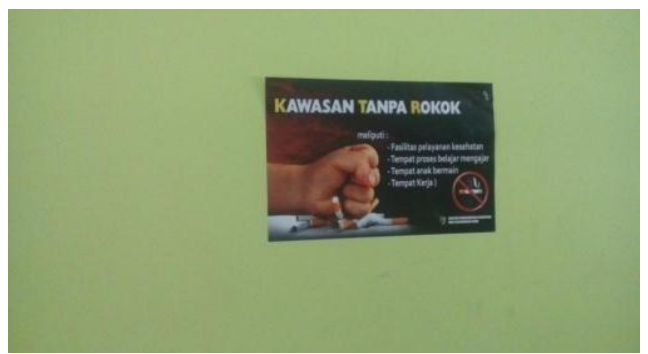

Gambar 1. KTR di Dindikbud Demak

c. Kawasan tanpa rokok sudaah terpenuhi dan terutama di tempat umum seperti dilingkungan kesehatan dan lingkungan pendidikan. Pendapat ini diperkuat dengan jawaban dari D1 dan D2 yang menyatakan seluruh pelayanan public di Kbupaten Demak harus bebas asap rokok terutama di Dinas Kesehatan dan Dinas Pendidikan

Tabel 4. Jumlah PAUD di Kabupaten Demak

\begin{tabular}{|c|l|c|c|c|}
\hline No & $\begin{array}{c}\text { Nama } \\
\text { Kecamatan }\end{array}$ & $\begin{array}{c}\text { Jumlah } \\
\text { Desa/Ke1 }\end{array}$ & Jumlah PAUD & Jumlah TK \\
\hline 1 & Demak & 19 & 19 & 36 \\
\hline 2 & Karangtengah & 17 & 17 & 23 \\
\hline 3 & Guntur & 20 & 20 & 31 \\
\hline 4 & Karangawen & 12 & 12 & 31 \\
\hline 5 & Mranggen & 19 & 19 & 59 \\
\hline 6 & Sayung & 20 & 20 & 24 \\
\hline 7 & Bonang & 21 & 21 & 32 \\
\hline 8 & Wedung & 20 & 20 & 21 \\
\hline 9 & Mijen & 15 & 15 & 18 \\
\hline 10 & Gajah & 18 & 18 & 22 \\
\hline 11 & Karanganyar & 17 & 17 & 23 \\
\hline 12 & Kebonagung & 14 & 14 & 25 \\
\hline 13 & Dempet & 16 & 16 & 30 \\
\hline 14 & Wonosalam & 21 & 21 & 30 \\
\hline Sumber : Dindikpora Kabupaten Demak, 2013 & \\
\hline
\end{tabular}

d. Pendidikan anak usia di Kabupaten Demak masih tergolong rendah, pendapat ini diperkuat dengan pendapat D1 dan D2 yang menyatakan masih rendahnya pendidikan anak usia dini di Kabupaten Demak dalam hal ini pendidikan anak usia dini dibedakan menjadi dua yaitu TK dan KB dengan persentasi masing-masing hasil sebagi berikut: TK $47 \%$ dan KB $38 \%$.

Tabel.5 : Jumlah sekolah ramah anak dan sekolah inklusi di Kabupaten Demak

\begin{tabular}{|c|c|c|}
\hline \multirow{2}{*}{\multicolumn{3}{|c|}{ Data Penyelenggara Pendidikan }} \\
\hline & & \\
\hline \multicolumn{3}{|c|}{ TAHUN 2016} \\
\hline No. & Jenis Sekolah & Tahun 2016 \\
\hline 1 & Sekolah Dasar (SD/MI) & 626 \\
\hline 2 & Sekolah Menengah Pertama (SMP /MTs) & 219 \\
\hline 3 & Sekolah Menengah Atas (SMA /SMK /MA) & 169 \\
\hline 4 & Sekolah Inklusi & 9 \\
\hline 5 & Sekolah Ramah Anak (SD/MI) & 626 \\
\hline 6 & Sekolah Akselarasi & 0 \\
\hline 7 & Pondok Pesantren & 180 \\
\hline Sumb & Der: Dindikpora Kabupaten Demak, 2016 & \\
\hline
\end{tabular}

e. Pentingnya keberadaan sekolah ramah anak dalam penilaian Kota Layak Anak menjadi salah satu indikator bahwa daerah tersebut memperhatikan hak-hak anak. Sekolah ramah anak di Kabupaten Demak sudah tepenuhi semua sekolah sudah menerapkan (100\%). Hal tersebut juga di kuatkan dengan pendapat D1 dan D2 yang menyatakan Kabupaten Demak sudah 
menerapkan sekolah ramah anak di sekolah-sekolah di semua jenjang pendidikan.

Tabel 6. APK dan APM tahun 2011-2012
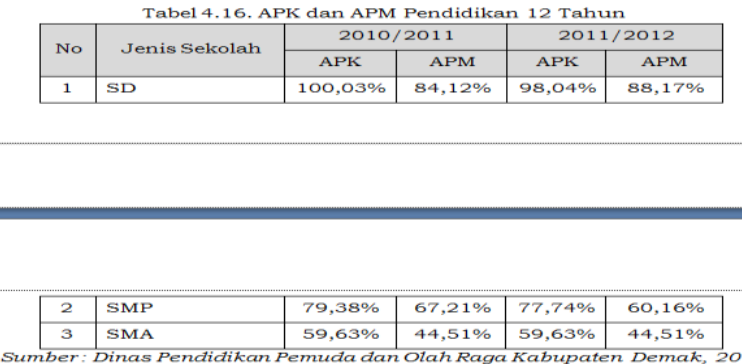

Tabel 7 APK dan APM tahun 2013-2014

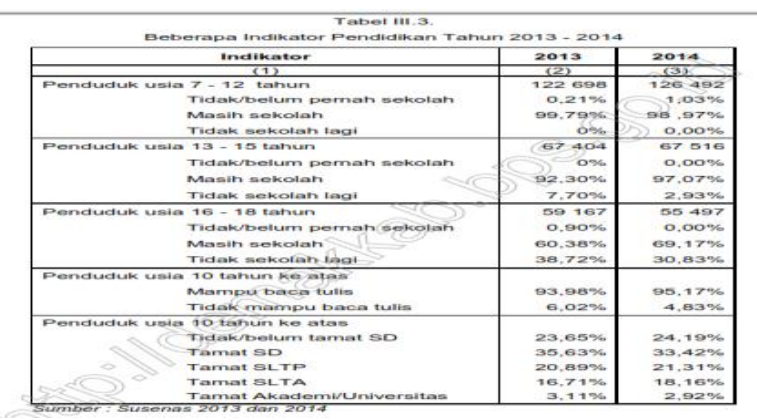

Tabel 8. Jumlah siswa putus sekolah tahun 2015

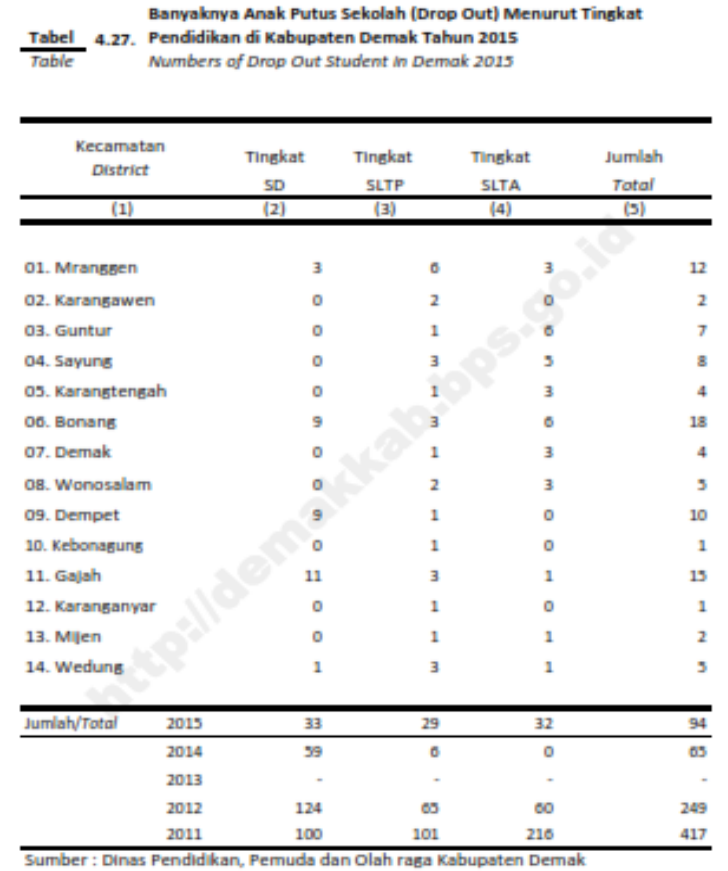

Source : National Educatian Service of Demak Regency.

Tabel 9. Data pilih gender, APK dan APM tahun 2017

\begin{tabular}{|c|c|c|c|c|}
\hline \multicolumn{4}{|c|}{$\begin{array}{l}\text { DATA PILIH GENDER DAN ANAK } \\
\text { KABUPATEN DEMAK } \\
\text { TAHUN } 2017\end{array}$} & \\
\hline \multirow{2}{*}{\multicolumn{5}{|c|}{ 1. PEMUDA DAN OLAHRAGA }} \\
\hline \multirow[b]{2}{*}{ No } & & & & \\
\hline & INDIKATOR & & Jumlah \\
\hline 1 & Jumlah murid SD $/ \mathrm{MI}$ & 60,913 & 56,267 & 117.180 \\
\hline 2 & Jumlah murid SD /Ml yang drop out (DO) & 73 & 44 & 117 \\
\hline 3 & Jumlah murid SMP & 28,486 & 27,506 & 55.992 \\
\hline 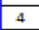 & Jumlah murid SMP $/ M T S$ yang drop out $(D O)$ & 113 & 123 & 236 \\
\hline 5 & Jumlah murid SMA/SMK /MA & 18,123 & 23,663 & 41.786 \\
\hline 6 & Jumlah murid SMA/SMK /MA yans drop out (DO) & 19 & 13 & 32 \\
\hline 7 & Jumlah Siswa SD /MI menerima Beasiswa & 27,069 & 33,085 & 60.154 \\
\hline 8 & Jumlah Siswa SMP /MTS menerima Beasiswa & 6,500 & 7,945 & 14.445 \\
\hline 9 & Jumlah Siswa SMA /MA menerima Eeasiswa & 4,198 & 5,131 & 9.329 \\
\hline 10 & Jumlah Siswa SMK menerima Beasiswa & 4,104 & 5,017 & 9.121 \\
\hline \multirow[t]{4}{*}{11} & Angla Partisipasi Kasar (APK) : & & & \\
\hline & - Tingkicat Pendidikan SD /MI & 107.69 & 107.69 & 107.69 \\
\hline & - Tingkat Pendidikan SMP /MTIs & 92.50 & 92.50 & 92.50 \\
\hline & - Tingkat Pendidikan SMA N Me & 97.90 & 97.90 & 97.90 \\
\hline \multirow[t]{4}{*}{12} & Angka Partisipasi Murni (APMM) & & & \\
\hline & \begin{tabular}{|l|}
-Tingkat Pendidikan SD /MII \\
\end{tabular} & 92.50 & 92.50 & 92.50 \\
\hline & \begin{tabular}{|l} 
- Tingkat Pendidikan SMP $/ M T s$ \\
\end{tabular} & 70.49 & 70.49 & 70.49 \\
\hline & - Tingkat Pendidikan SMA /MA & 67.97 & 67.97 & 67.97 \\
\hline \multirow[t]{4}{*}{13} & Angka Partisipasi Sekolah (APS) & & & \\
\hline & - Usia Kelompok $7-12$ th & 92.50 & 92.50 & 92.50 \\
\hline & - Usia Kelompok $13-15$ th & 70.49 & 70.49 & 70.49 \\
\hline & $16-18$ & 67.97 & 67.97 & 67.97 \\
\hline 14 & Rata-rata Lama Sekolah & 7.65 & 7.65 & 7.65 \\
\hline
\end{tabular}

f. Wajib belajar 12 tahun, angka partispisasi murni pada tahun 2012 sebesar $88,17 \%$ menjadi $92,50 \%$ pada tahun 2016, sekolah inklusi pada tahun 2014 sama dengan tahun 2017 yaitu sembilan sekolah inklusi, serta meningkatnya angka putus sekolah tahun 2017 sebanyak 117 siswa SD disbanding tahun 2015 sebanyak 33 siswa SD. Hal ini tidak berbeda dengan pendapat yang dikemukakan oleh D1 dan D2 yang menyatakan terjadi peningkatan angka partisipasi murni di Kabupaten Demak terutama pada jenjang sekolah dasar, keberadaan sekolah inklusi dari tahun 2013 sampai saat ini masih berjumlah sembilan sekolah lima jenjang pada Sekolah Dasar dan empat jenjang pada Sekolah Menengah Pertama (SMP).

Sedangkan angka putus sekolah mengalami peningkatan jika pada tahun 2015 terdapat 33 siswa putus sekolah pada jenjang sekolah dasar, 29 siswa setingkat SMP dan 32 siswa setingkat Sekolah Menengah Atas (SMA) maka pada tahun 2016 menjadi 117 siswa tingkat SD, 236 tingkat SMP dan 32 tingkat SMA. 
Tabel 10. ZoSS di Kabupaten Demak tahun 2013

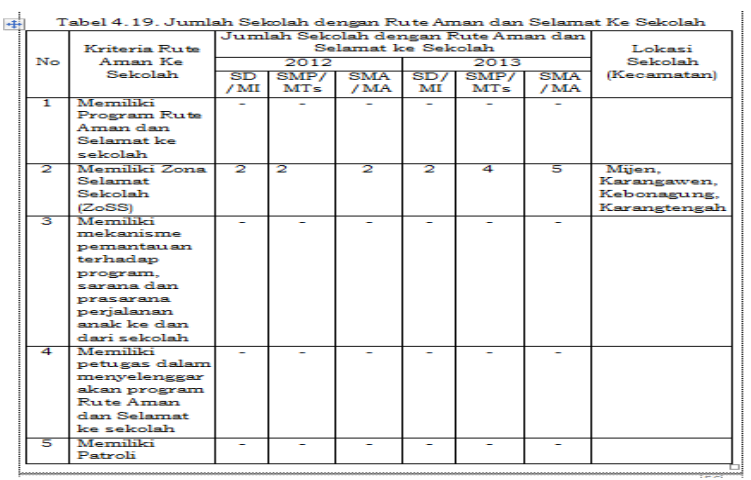

g. Sarana perjalanan anak dari dan ke sekolah atau ZoSS (Zona Selamat Sekolah) pada tahun 2017 tersedia di 19 tempat pada tahun 2017 jika sebelumnya pada tahun 2013 baru tersedia dua ZoSS terjadi peningkatan yang signifikan. Jika mengacu pada banyaknya sekolah yang berada dekat dengan jalan raya jumlah tersebut masih belum optimal. Data tersebut juga selaras dengan pendapat D1 dan D2 yang menyatakan terdapat peningkatan ZoSS di Kabupaten Demak yang semula berjumlah dua menjadi 19 pada tahun 2017.

h. Sarana kreasi dan rekreasi baik berbayar maupun gratis belum tersedia di Kabupaten Demak. Hal ini juga dipertegas oleh pendapat D1 dan D2 yang berpendapat belum ada sarana kreasi dan rekreasi di kabupaten Demak yang layak anak baik berbayar maupun gratis.

2. Implementasi KLA di sekolah

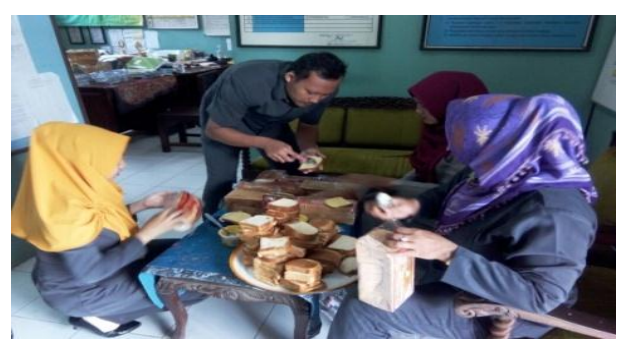

Gambar 2: Bantuan dari Blue Band di sekolah

a. Keterlibatan dunia usaha dalam pemenuhan hak anak di sekolah hasilnya sembilan dari sepuluh sekolah (S1-S10)mendapat bantuan dari dunia usaha dan bantuan masih bersifat temporar sedangkan satu sekolah belum pernah mendapat bantuan dari dunia usaha (S7). Pendapat ini diperkuat dengan hasil angket siswa dengan hasil sebagai berikut:

Tabel 11 Rekap angket siswa keterlibatan dunia usaha

\begin{tabular}{|c|c|c|c|}
\hline \multirow{2}{*}{ No } & \multirow{2}{*}{ Sekolah } & \multicolumn{2}{|c|}{ Keterlibatan dunia usaha } \\
\cline { 3 - 4 } & & Ya & Tidak \\
\hline 1 & A.1 & 28 & 1 \\
\hline 2 & A.2 & 0 & 18 \\
\hline 3 & A.3 & 0 & 2 \\
\hline 4 & A.4 & 8 & 15 \\
\hline 5 & A.5 & 18 & 23 \\
\hline 6 & A.6 & 5 & 17 \\
\hline 7 & A.7 & 4 & 2 \\
\hline 8 & A.8 & 28 & 6 \\
\hline 9 & A.9 & 17 & 22 \\
\hline 10 & A.10 & 19 & 5 \\
\hline
\end{tabular}

Dari angket tersebut dapat di jabarkan siswa dari sepuluh sekolah menilai keterlibatan dunia usaha terhadap mereka masih kurang hanya empat sekolah yang mayoritas siswanya memilih ada keterlibatan dunia usaha sedangkan enam sekolah menilai belum ada keterlibatan dunia usaha.

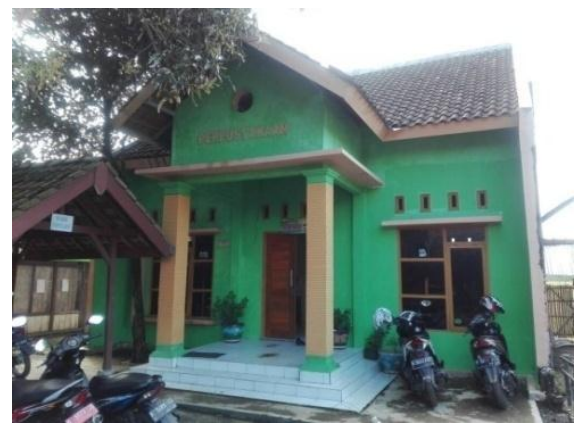

Gambar 3: Perpustakaan di SDN Kebonsari 1 Kecamatan Dempet

b. Fasilitas informasi dalam hal ini berkaitan dengan keberadaan sarana perpustakaan di sekolah dari sepuluh sekolah yang memiliki sarana fasilitas informasi berupa perpustakaan sembilan sekolah sudah terpenuhi sedangkan satu sekolah belum terpenuhi sarana fasilitas informasi karena keterbatasan lahan.

Tabel 12. Rekap angket siswa fasilitas informasi

\begin{tabular}{|c|c|c|c|}
\hline \multirow{2}{*}{ No } & Sekolah & \multicolumn{2}{|c|}{$\begin{array}{c}\text { Fasilitas informasi } \\
\text { (perpustakaan) }\end{array}$} \\
\cline { 2 - 4 } & & Ya & Tidak \\
\hline 1 & A.1 & 29 & 0 \\
\hline 2 & A.2 & 18 & 0 \\
\hline 3 & A.3 & 2 & 0 \\
\hline 4 & A.4 & 23 & 0 \\
\hline 5 & A.5 & 41 & 0 \\
\hline 6 & A.6 & 22 & 0 \\
\hline 7 & A.7 & 0 & 6 \\
\hline 8 & A.8 & 34 & 0 \\
\hline 9 & A.9 & 39 & 0 \\
\hline 10 & A.10 & 24 & 0 \\
\hline
\end{tabular}


Dari data tersebut semua siswa memilih terdapat fasilitas informasi di sekolah masingmasing kecuali A.7 yang belum tersedia fasilitas informasi. Penyebabnya adalah keterbatasan lahan. Hal ini juga diperkuat dengan pendapat kepala sekolah dari S1 sampai S10 hanya S7 yang menyatakan belum ada fasilitas informasi berupa perpustakaan di sekolahnya.

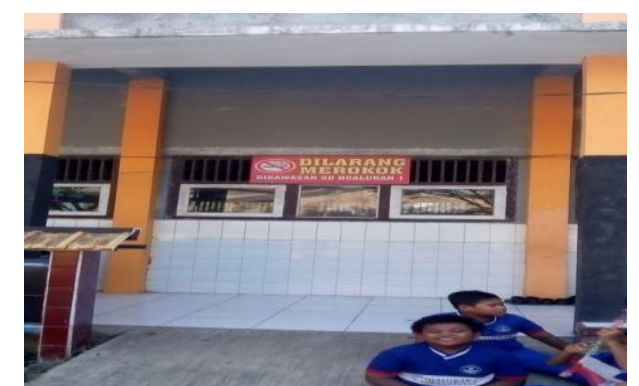

Gambar 4: Tanda larangan merokok di sekolah

c. Semua sekolah sudah menerapkan kawasan tanpa rokok disatuan pendidikan masing-masing ini ditandai dengan adanya tanda larangan merokok, meskipun tanda larangan merokok baru tersedia di lima sekolah dengan kondisi yang berbeda-beda.

Dari pendapat S1 sampai S10 semua menyatakan larangan merokok di sekolah.

Tabel 13. Rekap angket siswa kawasan tanpa rokok

\begin{tabular}{|c|c|c|c|c|c|}
\hline \multirow{2}{*}{ No } & \multirow{2}{*}{\begin{tabular}{c} 
Sekolah \\
\cline { 3 - 6 }
\end{tabular}} & \multicolumn{2}{|c|}{$\begin{array}{c}\text { Kawasan tanpa } \\
\text { rokok }\end{array}$} & \multicolumn{2}{c|}{$\begin{array}{c}\text { Tanda larangan } \\
\text { merokok }\end{array}$} \\
\cline { 3 - 6 } & & Ya & Tidak & Ya & Tidak \\
\hline 1 & A.1 & 2 & 27 & 29 & 0 \\
\hline 2 & A.2 & 18 & 0 & 18 & 0 \\
\hline 3 & A.3 & 2 & 0 & 2 & 0 \\
\hline 4 & A.4 & 23 & 0 & 0 & 23 \\
\hline 5 & A.5 & 41 & 0 & 0 & 41 \\
\hline 6 & A.6 & 2 & 20 & 0 & 22 \\
\hline 7 & A.7 & 0 & 6 & 0 & 6 \\
\hline 8 & A.8 & 16 & 18 & 0 & 34 \\
\hline 9 & A.9 & 39 & 0 & 39 & 0 \\
\hline 10 & A.10 & 24 & 0 & 24 & 0 \\
\hline
\end{tabular}

Dari data tersebut dapat dijabarkan kawasan tanpa rokok di sekolah dari sepuluh sekolah yang dilakukan penelitian enam sekolah mayoritas siswa memilih terdapat kawasan tanpa rokok di sekolahnya, tiga sekolah mayoritas siswanya memilih tidak terdapat kawasan tanpa rokok disekolahnya dan satu sekolah dengan hasil yang hamper berimbang. Sedangkan untuk tanda larangan merokok siswa memilih lima sekolah terdapat tanda larangan merokok dan lima sekolah tidak ada tanda larangan merokok.

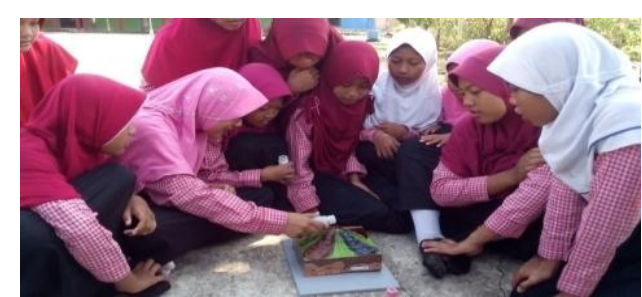

Gambar 5: Siswa praktik aktivitas gunung berapi

d. Sekolah ramah anak, dari hasil wawancara, angket dan observasi semua sekolah sudah mengimpelementasikan sebagai sekolah amah anak. baik dari kepala sekolah dan siswa semua (100\%) berpendapat sekolah ramah anak.

e. Belum optimalnya dalam melaksanakan wajib belajar 12 tahun di sekolah ini dapat diketahu dari sembilan dari sepuluh sekolah sudah melaksanakan wajib belajar 12 tahun sedangkan satu sekolah belum melaksanakan karena sekolah tersebut baru berdiri, sepuluh sekolah tidak termasuk sekolah inklusi dan masih terdapat siswa putus sekolah di beberapa SD.

Tabel 14. Rekap angket siswa wajib belajar 12 tahun

\begin{tabular}{|l|l|l|l|l|l|l|l|}
\hline \multirow{2}{*}{ No } & \multirow{2}{*}{ Sekolah } & \multicolumn{2}{|l|}{ Wajib belajar } & \multicolumn{2}{l|}{$\begin{array}{l}\text { Sekolah } \\
\text { inklusi }\end{array}$} & \multicolumn{2}{l|}{$\begin{array}{l}\text { Siswa } \\
\text { out }\end{array}$} \\
\cline { 3 - 8 } & & Ya & Tidak & Ya & Tidak & Ya & Tidak \\
\hline 1 & A.1 & 29 & 0 & 0 & 29 & 0 & 29 \\
\hline 2 & A.2 & 4 & 14 & 8 & 10 & 16 & 2 \\
\hline 3 & A.3 & 2 & 0 & 0 & 2 & 0 & 2 \\
\hline 4 & A.4 & 23 & 0 & 10 & 13 & 18 & 5 \\
\hline 5 & A.5 & 41 & 0 & 27 & 14 & 20 & 21 \\
\hline 6 & A.6 & 19 & 3 & 0 & 22 & 6 & 16 \\
\hline 7 & A.7 & 6 & 0 & 0 & 6 & 4 & 2 \\
\hline 8 & A.8 & 34 & 0 & 0 & 34 & 0 & 34 \\
\hline 9 & A.9 & 37 & 2 & 21 & 8 & 13 & 26 \\
\hline 10 & A.10 & 24 & 0 & 0 & 24 & 0 & 24 \\
\hline
\end{tabular}

Dari data tersebut untuk indikator wajib belajar 12 tahun, siswa sebagian besar melanjutkan ke jenjang pendidikan selanjutnya baik itu SMP maupun Mts, keberadaan sekolah inklusi dua dari sekolah menyatakan terdapat teman yang berkebutuhan khusus, enam sekolah tidak terdapat siswa yang berkebutuhan khusus dan dua sekolah mempunyai teman yang berkebutuhan khusus namun sudah mutasi ke sekolah luar biasa.

Siswa putus sekolah dari sepuluh sekolah yang diteliti empat sekolah tidak terdapat siswa putus sekolah sedngkan sisanya masih terdapat siswa putus sekolah. 


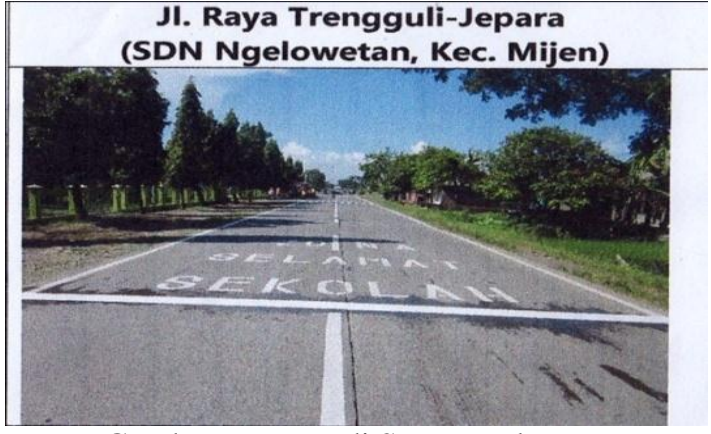

Gambar 6: Zoss di SDN Ngelowetan

f. Saran perjalanan dari dan ke sekolah, dari sepuluh sekolah dua sekolah memiliki ZoSS dengan kondisi layak sedangkan delapan sekolah belum layak.

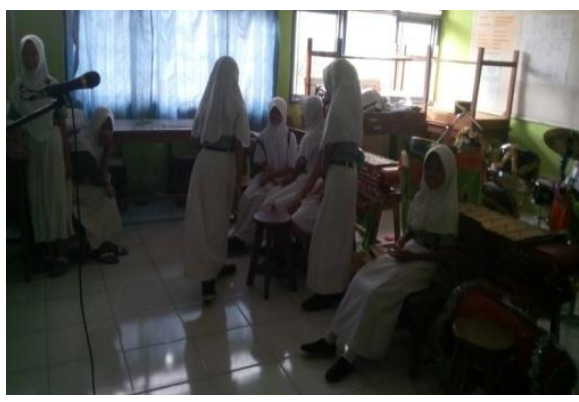

Gambar 5. Sarana pengembangan kreatifitas siswa

Tabel 15. Rekap angket siswa ZoSS

\begin{tabular}{|c|c|c|c|c|c|c|c|}
\hline \multirow{2}{*}{ No } & Sekolah & \multicolumn{2}{|c|}{ ZoSS } & \multicolumn{2}{c|}{$\begin{array}{c}\text { Mekanisme } \\
\text { pemantauan }\end{array}$} & \multicolumn{2}{c|}{$\begin{array}{c}\text { Pendidikan lalu } \\
\text { lintas }\end{array}$} \\
\cline { 3 - 8 } & & Ya & Tidak & Ya & Tidak & Ya & Tidak \\
\hline 1 & A.1 & 0 & 29 & 21 & 8 & 29 & 0 \\
\hline 2 & A.2 & 0 & 18 & 18 & 0 & 18 & 0 \\
\hline 3 & A.3 & 2 & 0 & 0 & 2 & 2 & 0 \\
\hline 4 & A.4 & 23 & 0 & 23 & 0 & 23 & 0 \\
\hline 5 & A.5 & 41 & 0 & 25 & 16 & 41 & 0 \\
\hline 6 & A.6 & 22 & 0 & 22 & 0 & 22 & 0 \\
\hline 7 & A.7 & 0 & 6 & 6 & 0 & 6 & 0 \\
\hline 8 & A.8 & 34 & 0 & 34 & 0 & 34 & 0 \\
\hline 9 & A.9 & 0 & 39 & 0 & 39 & 39 & 0 \\
\hline 10 & A.10 & 24 & 0 & 0 & 24 & 24 & 0 \\
\hline
\end{tabular}

Dari data tersebut dapat diperoleh hasil bahwa tiga dari sepuluh sekolah siswa meilih terdapat ZoSS di sekolahnya sedangkan tujuh sekolah belum meiliki fasilitas ZoSS. Mekanisme pemantauan dari sepuluh sekolah angket delapan sekolah menunjukkan terdapat pemantauan perjalanan siswa dari dan ke sekolah sedangkan tiga sekolah belum ada mekanisme pemantauannya. Semua siswa memilih terdapat pendidikan berlalu lintas di sekolahnya.

Hal tersebut senada dengan pendapat kepala sekolah yang menyatakan sudah adanya zona selamat sekolah, sudah ada pemantauan dan sudah diajarkannya pendidikan berlalu lintas di sekolah. g. Fasilitas pengembangan ketrampilan berupa sarana kreasi dan rekreasi, dua dari sepuluh sekolah memiliki sarana kreatifitas siswa dengan kondisi sangat layak, tujuh sekolah dengan kondisi layak dan satu sekolah dengan kondisi belum layak.

Tabel 16. Rekap angket siswa Fasilitas kreasi dan rekreasi

\begin{tabular}{|c|c|c|c|c|c|}
\hline \multirow{2}{*}{ No } & \multirow{2}{*}{ Sekolah } & $\begin{array}{c}\text { Sarana kreasi dan } \\
\text { rekreasi }\end{array}$ & \multicolumn{2}{|c|}{ Akses } \\
\cline { 3 - 6 } & Ya & Tidak & Ya & Tidak \\
\hline 1 & A.1 & 29 & 0 & 29 & 0 \\
\hline 2 & A.2 & 18 & 0 & 18 & 0 \\
\hline 3 & A.3 & 2 & 0 & 2 & 0 \\
\hline 4 & A.4 & 23 & 0 & 23 & 0 \\
\hline 5 & A.5 & 41 & 0 & 37 & 0 \\
\hline 6 & A.6 & 22 & 0 & 22 & 0 \\
\hline 7 & A.7 & 6 & 0 & 6 & 0 \\
\hline 8 & A.8 & 34 & 0 & 34 & 0 \\
\hline 9 & A.9 & 39 & 0 & 39 & 0 \\
\hline 10 & A.10 & 24 & 0 & 24 & 0 \\
\hline
\end{tabular}

Keberadaan fasilitas kreasi dan rekreasi di sekolah dapat dibuktikan dengan semua siswa di sekolah memilih terdapat fasilitas di sekolahnya dan semua siswa dapat menggunakan fasilitas tersebut. Hal senada juga di sampaikan S1 sampai S10 yang menyatakan sekolah meiliki fasilitas kreasi dan rekreasi dan dapat diakses oleh semua siswa.

\section{PENUTUP \\ Simpulan}

Dari penelitian ini dapat disimpulkan: (1) implementasi KLA dalam bidang pendidikan belum optimal, dua dari delapan indikator sudah terpenuhi yatu: kawasan tanpa rokok (no smoking area) dan sekolah ramah anak (child friendly school) sedangkan enam belum terpenuhi meliputi: keterlibatan dunia usaha (coorperate social responsibility), fasilitas informasi (information facility), pendidikan anak usia dini (PAUD), wajib belajar 12 tahun (compulsory education policy of 12 years), zona selamat sekolah (ZoSS) and facilities of creation and recreation. (2) implementasi KLA di sekolah dari tujuh indikator, dua indikator belum terpenuhi terpenuhi meliputi bantuan dunia usaha (Coorperate social responsibility) dan fasilitas informasi (information facility) dan lima indikator sudah terpenuhi yaitu: kawasan tanpa rokok (no smoking area), sekolah ramah anak (child friendly school), wajib belajar 12 tahun, zona selamat sekolah (ZoSS) dan sarana kreasi dan rekreasi (facilities of creation and recreation) 


\section{Saran}

Kebijakan harus direncanakan secara matang. Perlunya pengawasan secara komprehensif baik dalam perencanaan, pelaksanaan dan evaluasi antar pemangku kebijakan, sarana dan prasarana dalam pemenuhan Kota Layak Anak perlu ditingkatkan, anak-anak sebagai objek langsung kebijakan dapat diperhatikan pemenuhan kebutuhannya baik fisik maupun non fisik, sekolah sebagai tempat belajar dapat memperhatiak hak-hak anak secara maksimal

\section{DAFTAR PUSTAKA}

Abimanyu, Soedjipto. 2014. Babad Tanah Jawi. Yogyakarta: Laksana

Hamdi, Muchlis. 2014. Kebijakan Publik. Bogor: Ghalia Indonesia.

Hamudy, Moh Ilham A. 2015. Upaya Mewujudkan Kota Layak Anak di Surakarta dan Makassar. Diunduh tanggal 3 Maret 2017.
Lynch,K. 1977.Growing up in Cities: Studies of the Spatial Environment of Adolescencein Cracow, Melbourne, Mexico City, Salta, Toluca and Warsawa, The MIT Pressdan UNESCO, Cambridge.

Moran, Michael et al. 2015. Handbook Kebijakan Publik. Bandung: Nusa Media.

Moleong, Lexy J. 2011. Metodologi Penelitian Kualitatif. Bandung: Remaja Rosda karya.

Munadi, Muhammad dan Barnawi. 2011. Kebijakan Publik Di Bidang Pendidikan. Yogyakarta: Ar-Ruzz Media.

Rumtianingsih, Irma. 2014. Kota Layak Anak Dalam Perlindungan Anak. Ponorogo.: STAIN Ponorogo.

Sugiyono. 2015. Memahami Penelitian Kualitatif. Bandung: Alfabeta

Suparnyo, 2014. Hukum Perlindungan Anak: Kudus, FKIP Universitas Muria Kudus. 